University of Nebraska - Lincoln

DigitalCommons@University of Nebraska - Lincoln

$9-1990$

\title{
RECENT SECULAR VARIATIONS IN THE EXTENT OF NORTHERN HEMISPHERE SNOW COVER
}

\author{
David A. Robinson \\ Rutgers University \\ Kenneth F. Dewey \\ University of Nebraska-Lincoln, kdewey@unl.edu
}

Follow this and additional works at: https://digitalcommons.unl.edu/geosciencefacpub

Part of the Earth Sciences Commons

Robinson, David A. and Dewey, Kenneth F., "RECENT SECULAR VARIATIONS IN THE EXTENT OF NORTHERN HEMISPHERE SNOW COVER" (1990). Papers in the Earth and Atmospheric Sciences. 464. https://digitalcommons.unl.edu/geosciencefacpub/464

This Article is brought to you for free and open access by the Earth and Atmospheric Sciences, Department of at DigitalCommons@University of Nebraska - Lincoln. It has been accepted for inclusion in Papers in the Earth and Atmospheric Sciences by an authorized administrator of DigitalCommons@University of Nebraska - Lincoln. 


\title{
RECENT SECULAR VARIATIONS IN THE EXTENT OF NORTHERN HEMISPHERE SNOW COVER
}

\author{
David A. Robinson \\ Rutgers University, New Brunswick, New Jersey \\ Kenneth F. Dewey \\ University of Nebraska, Lincoln, Nebraska
}

\begin{abstract}
Northern hemisphere snow cover during 1988 and 1989 was at its lowest extent since the advent of reliable satellite snow-cover monitoring in 1972; running some 8-10\% below the eighteen-year annual mean of 25.7 million $\mathrm{km}^{2}$. Monthly minima for the period of record occurred six times during these two years. In general, the last nine years of the satellite record had less extensive cover than the 1972-80 interval. Negative anomalies during the 1980 s were largest over Eurasia in all seasons, and in the Spring over North America. Hemispheric seasonal means for the most recent nine years were $3.7 \%$ to $8.4 \%$ lower than those between 1972 and 1980. Results are based on analyses of National Oceanic and Atmospheric Administration weekly snow charts, which are produced from visible satellite imagery.
\end{abstract}

\section{Introduction}

Snow is a key variable in the global climate system, influencing the global heat budget chiefly through its effect of increasing surface albedo [Kung et al., 1964, Robinson and Kukla, 1985]. Accurate information on snow cover is essential for understanding details of climate change [Wiesnet and Matson, 1976, Dewey, 1987]. It has been suggested that this information might make snow extent a useful index for detecting and monitoring such change [Barry, 1985, Schlesinger, 1986]. Currently, the best information concerning continental snow cover is provided by NOAA weekly snow charts. These northern hemisphere charts are produced from a visual interpretation of photographic copies of visible satellite imagery by trained meteorologists [Matson et al., 1986]. Other potential sources of information on a contimental scale are less reliable. They include ground-station observations of snow cover, which are primarily concentrated in the lower elevations of the middle latitudes; thus limiting their utility to regional climate investigations. Also, NASA has charted snow cover using microwave satellite data since the late 1970s [Chang et al., 1987]; however, at present, inaccuracies in microwave charting in a number of locations limit the utility of this technique [Robinson et al., 1984, Hall et al., 1986].

\section{NOAA snow charts}

NOAA weekly snow charts depict boundaries between snow-covered and snow-free land surfaces. These snow lines

Copycight 1990 by the American Geophysical Union.

Paper number 90GL01736

0094-8276/90/90GL-01736\$03.00 are delimited by recognizing characteristic textured surface features and brightnesses of snow-covered lands. The charts show boundaries on the last day that the surface in a given region is seen. This most often is the final or penultimate day of the week, although in regions with persistent cloudiness it may extend back over one week [Kukla and Robinson, 1981]. This illustrates a difficulty in applying chart results on a weekly or local basis. Also, occasional regional inaccuracies may result from low solar illumination, and from problems of recognizing snow cover in forested regions.

NOAA has produced northern hemisphere snow charts since 1966 . However, it is recognized that in early years the snow extent was underestimated, especially during the Fall [Kukla and Gavin, 1984, Ropelewski, 1984]. Charting improved considerably in 1972 with the deployment of the Very High Resolution Radiometer (VHRR) on board NOAA polar-orbiting satellites. The VHRR had a spatial resolution in the visible portion of the spectrum of one kilometer (Advanced VHRR: $1.1 \mathrm{~km}$ ), while the resolution of earlier sensors was no greater than four kilometers. Since 1972, charting accuracy is such that this product is considered suitable for continentalscale climate studies [Wiesnet et al., 1987]. The first analysis of hemispheric snow extent based on NOAA charts was performed by Kukla and Kukla (1974). Examinations continued in subsequent years [Matson and Wiesnet, 1981, Foster et al., 1986], although the most recent analysis only included data through 1981 [Matson et al., 1986].

Snow charts were digitized on a weekly basis using the National Meteorological Center's primitive equation model grid. This is an $89 \times 89$ cell northem hemisphere grid, with cell resolution ranging from 16,000 to $42,000 \mathrm{~km}^{2}$ [Dewey and Heim, 1982]. If a cell was interpreted to be fifty percent or more covered by snow it was considered to be completely covered. Monthly continental and hemispheric extents were subsequently calculated.

\section{Results}

The greatest monthly extent of snow cover in the Northern Hemisphere during the past eighteen years was $\mathbf{5 2 . 8}$ million $\mathrm{km}^{2}$ in February 1978 (Table 1). On the low side, no monthly extent exceeded 42.9 million $\mathrm{km}^{2}$ in 1981 . Mean monthly snow cover was less extensive in recent years; eighteen-year minima occurred for March, April, May, July, August and October in either 1988 or 1989 . With only one exception, all monthly minima occurred in the 1980 s. Conversely, eleven of the twelve monthly maxima were observed in the first half of the record. The only monthly maximum in the most recent half of the record was in November 1985. 
TABLE 1. Monthly and annual snow cover (million $\mathrm{km}^{2}$ ) over northern hemisphere lands during the period Jan 1972 through Dec 1989.

\begin{tabular}{|c|c|c|c|c|}
\hline & MAXIMUM (vr) & MINIMUM $(y r)$ & AVERAGE & STD DEV \\
\hline $\operatorname{Jan}$ & 51.0 (1979) & 41.2 (1981) & 46.5 & 2.4 \\
\hline Feb & 52.8 (1978) & 42.9 (1981) & 46.5 & 2.7 \\
\hline Mar & $43.5 \quad(1978,79)$ & 37.9 (1989) & 41.0 & 1.8 \\
\hline Apr & $36.3(1979)$ & 27.4 (1988) & 31.8 & 2.2 \\
\hline May & 24.6 (1978) & 17.1 (1989) & 20.9 & 2.2 \\
\hline Jun & 15.5 (1976) & 7.5 (1984) & 11.6 & 2.3 \\
\hline Jul & 6.7 (1979) & $3.6(1982,88)$ & 5.2 & 1.2 \\
\hline Aug & $5.3(1980)$ & 2.6 & 3.9 & 0.9 \\
\hline Sep & 9.9 (1972) & 4.3 (1984) & 5.7 & 1.3 \\
\hline Oct & $31.6(1976)$ & $11.5(1988)$ & 18.5 & 4.6 \\
\hline Nov & 39.6 (1985) & 29.5 (1979) & 33.8 & 2.3 \\
\hline Dec & 45.6 (1973) & 37.4 (1980) & 42.5 & 2.4 \\
\hline Annual & 28.3 (1978) & $23.5 \quad(1988)$ & 25.7 & 1.2 \\
\hline
\end{tabular}
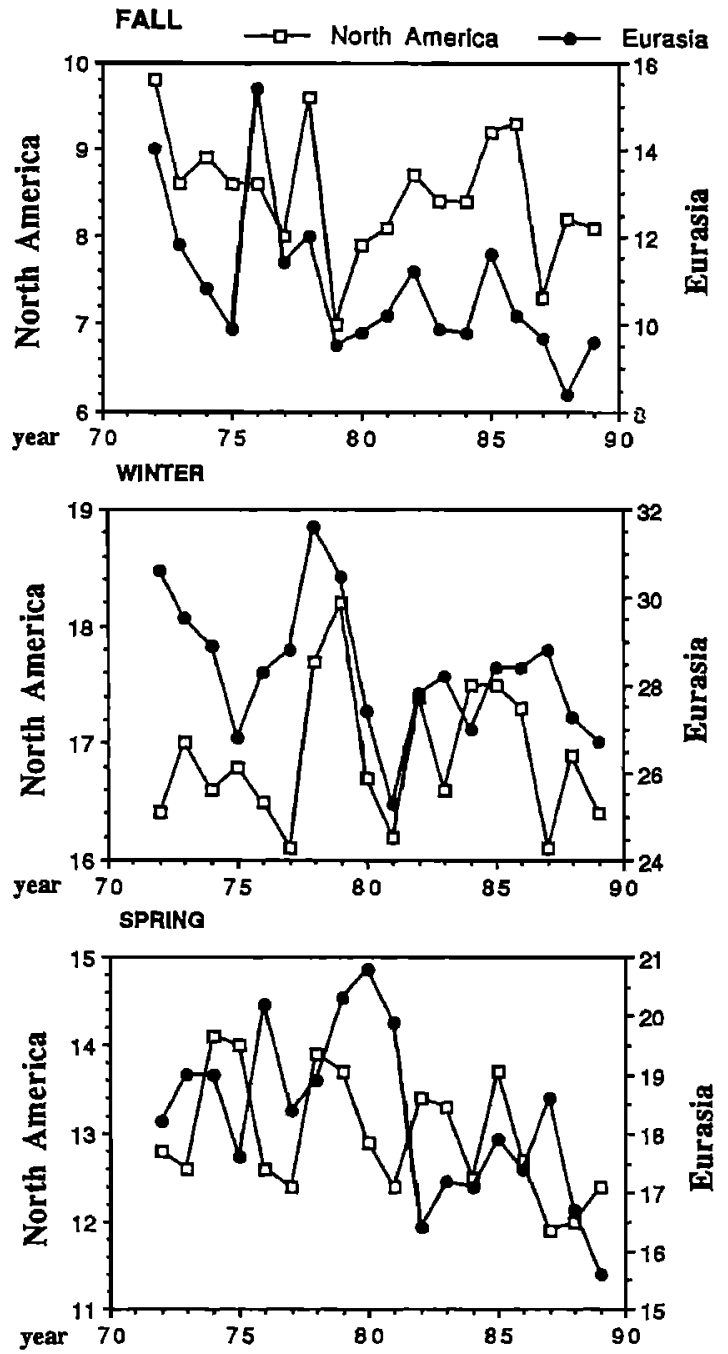

Fig. 1. Seasonal snow cover (million $\mathrm{km}^{2}$ ) over Eurasia and North America from Winter 1971/72 to Fall 1989. Fall: SON; Winter: DJF; Spring: MAM. Note the different scale for each continent.
Eurasian snow cover dominates the hemispheric signal (Figure 1). North american mean cover was on average $22 \%$ less extensive than eurasian cover in the Fall, $40 \%$ less in Winter, and 29\% less in Spring. In recent years, noticeable decreases in seasonal snow cover occurred in all seasons over Eurasia, and in the Spring over North America (Table 2). Hemispheric seasonal means for the most recent nine years were $3.7 \%$ to $8.4 \%$ lower than those between 1972 and 1980 .

Mean annual snow cover was less extensive over the Northern Hemisphere during the latter half of the satellite record. This change in cover between the 1972-80 and 198189 intervals is significant at the 0.01 level (t-test). This also holds true over Eurasia, but results are not significant at or above the 0.05 level over North America. No significant change ( $\geq 0.05$ level) in interannual variability is apparent on a hemispheric or continental scale between the two intervals.

TABLE 2. Mean seasonal snow cover (million $\mathrm{km}^{2}$ ) over northern hemisphere $(\mathrm{NH})$ continents for Winter $1971 / 72$ to Fall 1980, and Winter 1980/81 to Fall 1989. The percent decrease in extent between the first and latter halves of the study era is also shown. Eurasia (Eur), North America (NA).

\begin{tabular}{|c|c|c|c|c|}
\hline & Eur $^{\mathbf{F}}$ & $\begin{array}{l}\text { ALL } \\
\text { NA NH }\end{array}$ & $\begin{array}{l}\text { WINTER } \\
\text { Eur NA NH }\end{array}$ & $\begin{array}{l}\text { SPRING } \\
\text { Eur NA NH }\end{array}$ \\
\hline $\begin{array}{l}72-80 \\
81-89\end{array}$ & $\begin{array}{l}11.6 \\
10.1\end{array}$ & $\begin{array}{ll}8.6 & 20.2 \\
8.4 & 18.5\end{array}$ & $\begin{array}{llll}29.2 & 16.9 & 46.1 \\
27.5 & 16.9 & 44.4\end{array}$ & $\begin{array}{lll}19.2 & 13.2 & 32 \\
17.4 & 12.7 & 30\end{array}$ \\
\hline decr. & 12.9 & 8.4 & 5.8 & 9.4 \\
\hline
\end{tabular}

Twelve-month running means of hemispheric snow extent averaged 25.7 million $\mathrm{km}^{2}$ (standard deviation: 1.2 million $\mathrm{km}^{2}$ ), and ranged from 28.6 million $\mathbf{k m}^{2}$ (May 78-Apr 79) to 23.0 million $\mathrm{km}^{2}$ (Oct 88-Sep 89) (Figure 2). The hemispheric running mean further illustrates recent decreases in cover. Only in the mid 1980 s was there a short-lived increase in hemispheric cover, which was largely a north american occurrence. By 1988, twelve-month running means of north american snow cover fell to levels previously only 

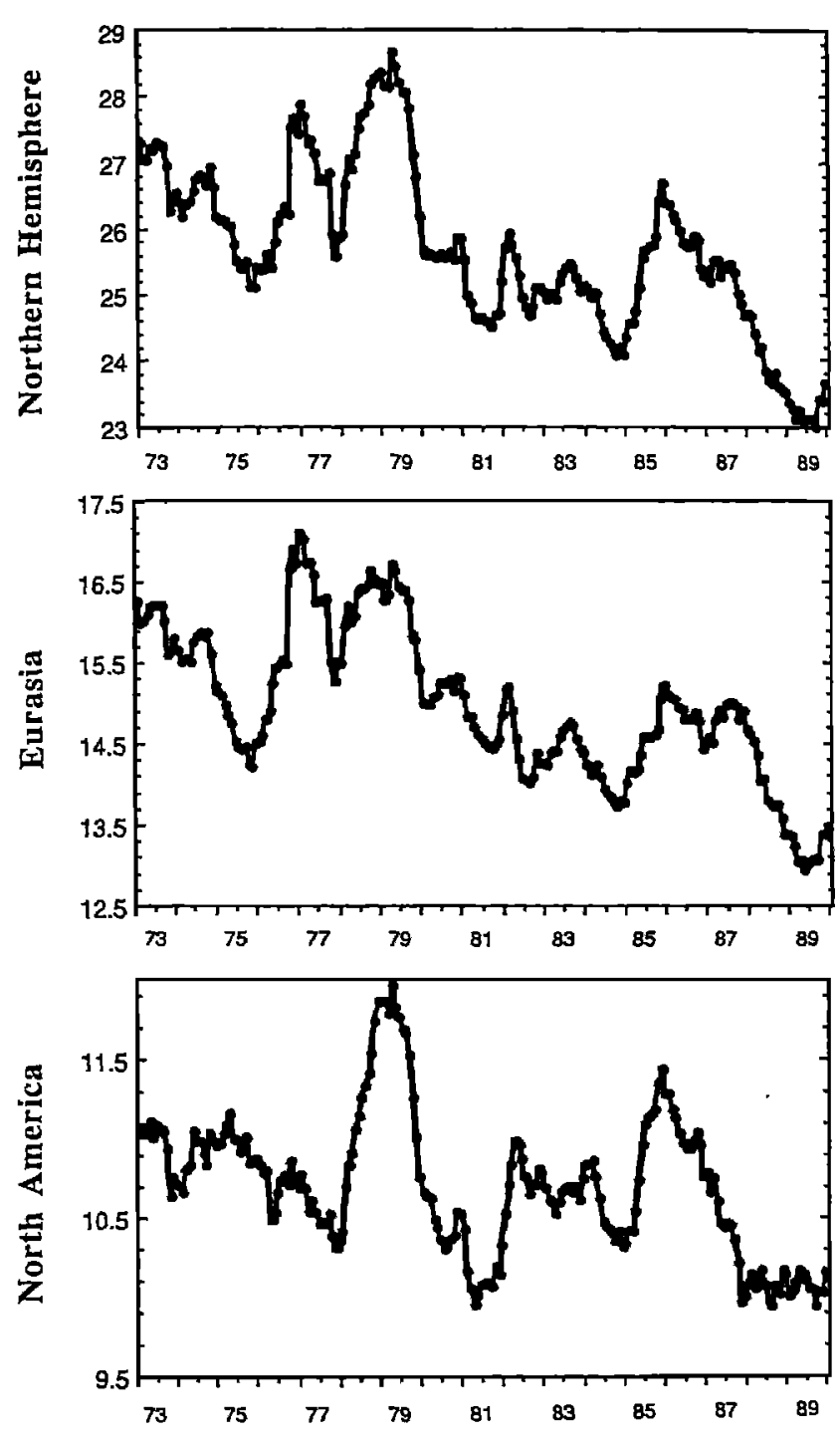

Fig. 2. Twelve-month running means of snow cover (million $\mathrm{km}^{2}$ ) over northern hemisphere lands for the period Jan 1972 through Dec 1989. Also partitioned for Eurasia and North America. Note the different scale for each graph.

observed in 1981, and remained there at the end of 1989. Running means of eurasian cover were below the previous 1984 low throughout 1988 and 1989. Recent minima were a function of the record low months observed over the past two years, and the absence of particularly snowy months during this period over either continent.

\section{Discussion and Conclusions}

The reduced extent of snow cover over northem hemisphere lands during the 1980s occurred during one of the warmest decades of the past century [Jones et al., 1986, Jones, 1988, Hansen and Lebedeff, 1987, 1988]. An examination of hemispheric twelve-month running means of snow cover and surface air temperature from 1972-1987 shows a striking relationship between the two (Figure 3). This association may in part be due to a snow-albedo feedback. Such a feedback is incorporated in general circulation models [Hansen et al.,
1984, Dickinson et al., 1987], and results in an amplification of warming in model simulations which incorporate increased concentrations of greenhouse gases [Manabe and Wetherald, 1980, Hansen et al., 1983, Schlesinger, 1986].

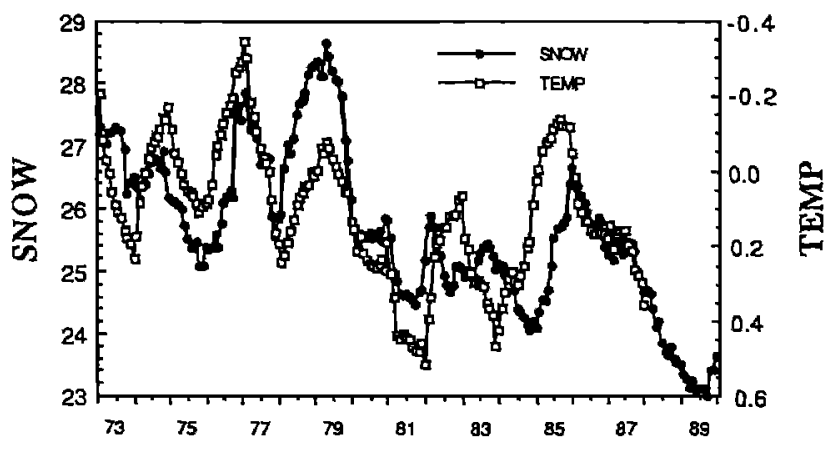

Fig. 3. Twelve-month running means of snow cover (million $\mathrm{km}^{2}$ ) and departures of surface air temperature $\left({ }^{\circ} \mathrm{C}\right)$ over the Northern Hermisphere for Jan 1972 through Dec 1989 (snow) and Jan 1972 through Dec 1987 (temp.). Temperature data were gathered from land-based stations and fixed-position weather ships [Jones et al., 1986, Jones, 1988].

However, it is premature to infer an anthropogenic cause for the recent decrease in hemispheric snow cover. These changes may have been associated with natural variations of atmospheric circulation, temperature, precipitation and/or other climate variables. To address adequately the natural versus anthropogenic issue, the long-term natural variability of snow cover must first be identified and relationships between snow and other climate variables more firmly established. This can be accomplished on a local, and in some cases regional, basis using lengthy ( +50 year) station records and the everexpanding satellite data base. A long-term snow set has recently become available for close to 1000 stations throughout the U.S, [Robinson, 1988], and similar files for the USSR should be at hand within the next year (T. Karl, per. com).

The relative simplicity of observing hemispheric snow cover from satellites, the critical role that snow cover has in the global heat budget, and the expected role of snow feedbacks in anthropogenic climate change support the continued diligent monitoring of snow cover.

Acknowledgments. Appreciation is extended to the Satellite Applications Branch of NOAA for the monthly snow cover data. Thanks also to G. Kukla for comments on the manuscript. D. Robinson's work is supported by the Climate Dynamics Program of the National Science Foundation, under grant ATM 89-96113.

\section{References}

Barry, R.G., The cryosphere and climate change, in Detecting the Climatic Effects of Increasing Carbon Dioxide. U.S. Dept of Energy, DOE/ER 0235, 109-148, 1985.

Chang, A.T.C., J.L. Foster, and D.K. Hall, Nimbus-7 SMMR derived global snow cover parameters, Annals of Glaciology. 9, 39-44, 1987.

Dewey, K.F., Satellite-derived maps of snow cover frequency for the Northern Hemisphere, I. Cli. Appl. Met. 26. 
1210-1229, 1987.

Dewey, K.F., and R. Heim Jr., A digital archive of Northern Hemisphere snow cover, November 1966 through December 1980, Bull. A.M.S. 63, 1132-1141, 1982.

Dickinson, R.E., G.A. Meehl, and W.M. Washington, Icealbedo feedback in a $\mathrm{CO}_{2}$-doubling simulation, Climatic Change. 10, 241-248, 1987.

Foster, J., M. Owe, and C. Capen, Measurements of the north polar cap of Mars and the Earth's Northem Hemisphere ice and snow cover, Earth. Moon. Planets. 35, 223-235, 1986.

Hall, D.K., A.T.C. Chang, and J.L. Foster, Detection of the depth-hoar layer in the snow-pack of the Arctic coastal plain of Alaska, using satellite data, I. Glaciol. 32, 87-94, 1986.

Hansen, J., G. Russell, D. Rind, P. Stone, A. Lacis, S. Lebedeff, R. Ruedy, and L. Travis, Efficient threedimensional global models for climate studies: models I and II, Mon. Wea. Rev.. 111, 609-662, 1983.

Hansen, J., A. Lacis, D. Rind, G. Russell, P. Stone, I. Fung, R. Ruedy, and J. Lerner, Analysis of feedback mechanisms, in Climate Processes and Climate Sensitivity, Geophys. Monogr. Ser. vol. 29, AGU, 130-163, 1984.

Hansen, J., and S. Lebedeff, Global trends of measured surface air temperature, I. Geophys. Res., 92, 13345$13372,1987$.

Hansen, J., and S. Lebedeff, Global surface air temperatures: update through 1987, Geophys. Res, Let. 15, 323-326, 1988.

Jones, P.D., Hemispheric surface air temperature variations: recent trends and an update to 1987 , J. Climate. $1,654-$ 660, 1988.

Jones, P.D., S.C.B. Raper, R.S. Bradley, H.F. Diaz, P.M. Kelly, and T.M.L. Wigley, Northern Hemisphere surface air temperature variations: $1851-1984, \mathrm{~J}$. Cli. Appl. Met. 25, 161-179, 1986.

Kukla, G., and J. Gavin, Recent fluctuations of Northern Hemisphere snow cover in autumn, Proc. Eighth Annual NOAA Climate Diagnostics Workshop, Downsview, Ontario Canada, 189-196, 1984.

Kukla, G., and H.J. Kukla, Increased surface albedo in the Northem Hemisphere, Science, 183, 709-714, 1974.

Kukla, G., and D.A. Robinson, Accuracy of snow and ice monitoring, Snow Watch 1980. Glaciological Data. Report GD-5, 91-97, 1981.

Kung, E., R. Bryson, and D. Lenschow, Study of a continental surface albedo on the basis of flight measurements and structure of the Earth's surface cover over North America, Mon. Wea. Rey. 92, 543-563, 1964.
Manabe, S., and R.T. Wetherald, On the distribution of climate change resulting from an increase in $\mathrm{CO}_{2}$-content of the atmosphere, J. Atmos. Sci. 37, 99-118, 1980.

Matson, M., C.F. Ropelewski, and M.S. Varnadore, An atlas of satellite-derived Northern Hemispheric snow cover frequency, NOAA Atlas, 74 pp, 1986.

Matson, M., and D.R. Wiesnet, New data base for climate studies, Nature, 289, 451-456, 1981.

Robinson, D.A., Construction of a United States historical snow data base, Proc. 45th Eastern Snow Conference, 50 59, 1988.

Robinson, D.A., and G. Kukla, Maximum surface albedo of seasonally snow covered lands in the Northern Hemisphere, J. Cli. Appl, Met. 24, 402-411, 1985.

Robinson, D.A., K. Kunzi, G. Kukla, and H. Rott, Comparative utility of microwave and shortwave satellite data for all-weather charting of snow cover, Nature. 312 434-435, 1984.

Ropelewski, C.F., Satellite derived snow cover in climate diagnostics studies, Recent Advances in Civil Space Remote Sensing. Proc. Soc, of Photo-Optical Instrumentation Engineers Technical Symp. East '84, 1984.

Schlesinger, M.E., $\mathrm{CO}_{2}$-induced changes in seasonal snow cover simulated by the OSU coupled atmosphere-ocean general circulation model, Snow Watch '85. Glaciological Data. Report GD-18, 249-270, 1986.

Wiesnet, D.R., and M. Matson, A possible forecasting technique for winter snow cover in the Northern Hemisphere and Eurasia, Mon. Wea. Rev. 104, 828$835,1976$.

Wiesnet, D.R., C.F. Ropelewski, G.J. Kukla, and D.A. Robinson, A discussion of the accuracy of NOAA satellite-derived global seasonal snow cover measurements, Large Scale Effects of Seasonal Snow Cover, Proceedings Vancouver Symposium, IAHS Publ. no. $166,291-304,1987$.

David A. Robinson, Department of Geography, Rutgers University, New Brunswick, NJ 08903.

Kenneth F. Dewey, Department of Geography, University of Nebraska, Lincoln, NE 68588. 